Click www.researchjournal.co.in/online/subdetail.html to purchase.

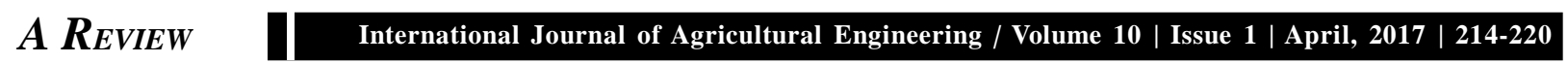

$\Rightarrow$ e ISSN-0976-7223 Visit us : www.researchjournal.co.in DOI: 10.15740/HAS/IJAE/10.1/214-220

\title{
Osmotic drying of pineapple
}

SANJEEV KUMAR AND R.N. SHUKLA

See end of the Paper for authors' affiliation

Correspondence to :

SANJEEV KUMAR

Department of Food Process Engineering, Vaugh School of Agricultural Engineering and Technology, Sam Higginbottom University of Agriculture Technology and Sciences, ALLAHABAD (U.P.) INDIA

Email : sk085347@gmail.com
- ABSTRACT : Osmotic dehydration in hot air drying of pineapple cubes by using sucrose solution is able to improve the quality like colour, aroma, texture, appearance as well as overall accepabilty. Regression equation is used to predict optimum condition for weight reduction, minimal solid gain, maximum water loss and physical properties of dehydrated pineapple cubes. Potassium metabisulphat is most useful for the browning inhibition. Osmotic and infrared dryings are reduced the water activity, which prevents the microbial growth. The dose of $1 \mathrm{kGy}$ radiation is adversely effective in eliminating the residual microbial load on pineapple cubes, thus ensuring microbial safety of the product sensorial accepted during storage. When calcium is use as a component of osmotic solution in the osmotic dehydration of pineapple cubes. Then the calcium is responsible for increasing the mechanical properties, microbial stability and physico-chemical properties of pineapple slices. By using high density polyethylene film inhibits the moisture content of the products and minimal quality deterioration of dehydrated pineapple slices. HDPE film having high moisture barrier material caused minimal change in moisture content of samples, and hence, minimal quality deterioration of dried pineapple slices. Mostly laminated aluminium (Al) is not affected by the ambient storage temperature and suitable for preserving dehydrated pineapple slices. Alone blanching pre-treatment is not suitable for the drying of pineapple slices due to disintegration of negative impact and cell wall observed on the sensory quality. While Sulphiting pre-treatment protects the ascorbic acid from degradation and improved effective moisture transport. In sensory evaluation of pre-treated dehydrated pineapple slices is highly the acceptable. combination of pre-treatments of: 60 per cent sucrose $/ 2500 \mathrm{ppm} \mathrm{SO} ; 40$ per cent sucrose $/ 60^{\circ} \mathrm{C}$ blanching $/ 2500 \mathrm{ppm} \mathrm{SO} ; 60^{\circ} \mathrm{C}$ blanching $/ 2500 \mathrm{ppm} \mathrm{SO}$ is suitable for production of dried pineapple slices. The application of different antibrowning agents can be used to prolong the shelf-life of fresh-cut pineapples. The predictions of water content and per cent charred pieces by quadratic surface models are validated with an additional drying experiment, and the use of such models to define multicriteria points of optimum. Drying rates and drying time of pineapple slices are affected by the blanching temperature-time combinations. Increasing the blanching temperature time combinations are increased drying times. The logarithmic model sufficiently describes the drying behaviour of blanched pineapple slices. The Fick's diffusion model is suitable for the experimental results which enabled the determination of the effective moisture diffusivity.

- KEY WORDS : Pretreatments, Drying, Drying models, Pineapple, Ascorbic acid, Osmotic dehydration

- HOW TO CITE THIS PAPER : Kumar, Sanjeev and Shukla, R.N. (2017). Osmotic drying of pineapple. Internat. J. Agric. Engg., 10(1) : 214-220, DOI: 10.15740/HAS/IJAE/10.1/214-220. 